\title{
ANALYSIS OF A TOPSOIL MOISTURE REGIME THROUGH AN EFFECTIVE PRECIPITATION INDEX FOR THE LOCALITY OF NITRA, SLOVAKIA
}

\author{
Peter RONČÁK ${ }^{1 *}$, Peter ŠURDA ${ }^{1}$, Justína VITKOVÁ ${ }^{1}$
}

\begin{abstract}
The aim of this work was to analyze and statistically confirm the relationship between the computed daily values of the Effective Precipitation Index (EP365) and the measured moisture content of the topsoil of a research site near Nitra, Slovakia. The statistical analysis (coefficients of determination) confirmed the strong correlation. Subsequently each day's mean of EP365 (MEP) was used to quantify the long-term deficit or surplus of the soil water supply in the individual years. The daily values of the EP365 index provide a more detailed view of the development of the topsoil's moisture regime. According to the deviation of EP (DEP) from the 14-year MEP, the most extreme dry periods prevailed during the years 2015, 2017 and 2018. Therefore, the 2012-2018period was evaluated as dry, and the topsoil moisture regime described through the MEP index was compared with the course of the MEP index from the normal (slightly humid) period of the years $2005-2011$.
\end{abstract}

Address

1 Institute of Hydrology SAS, Dúbravská cesta 9, 84104 Bratislava, Slovak Republic

* Corresponding author: roncak@uh.savba.sk

\section{Key words}

- Meteorological indices,

- Soil moisture regime,

- Droughts,

- Effective Precipitation Index.

\section{INTRODUCTION}

Climate change in recent decades has led to an increasing trend in droughts, and models predict that the global drought risk will further intensify in the $21^{\text {st }}$ century (Dai, 2013, Su et al., 2018). Drought is a stochastic natural hazard that is instigated by intense and persistent shortage of precipitation. Following an initial meteorological phenomenon, subsequent impacts are realized on agriculture and hydrology (Zargar, 2011).

Drought has also become an important research topic in Slovakia in recent years. Zuzulova et al. (2014) assessed the development of droughts in Slovakia during the period 1951-2010 and found a declining trend in the Palmer drought severity index for the Slovak Republic during the period 1951-1980 but an increasing trend during the period 1981-2010. Vido et al. (2015) observed the occurrence of drought at higher altitudes in the Tatra National Park, an important biological reserve of Central European fauna and flora. The results confirmed that the frequency of drought in the study area is cyclical, with an approximately 30 -year recurrence period. According to Takáč (2014), the dry periods in 2012 and 2013 significantly affected crop production in the agricultural regions of Slovakia. Nikolová (2016) confirmed the growing trend of the occurrence of severe or extreme droughts in the summer period for most of the stations studied in the lowlands of the Slovak Republic. Vido et al., (2016) analyzed the physiological response of woody plants in central Slovakia to the driest months of the year 2012. Sustek et al. (2017) documented the impact of the 2012 dry season on the decline in the number of beetle species in the High Tatras. Brezianska et al. (2018) analyzed the occurrence of drought and reduced soil water supplies in the localities of the Záhorská lowlands during the period 1961-2010. Hlavčová et al. (2016) expected an increase in the flows in the spring and winter months. On the other hand, in the summer and autumn months was expected a decreasing trend in the flows on the upper Hron River basin. Fendekova et al. (2018) examined a time series of runoff data from twelve river basins in Slovakia in the period 1981-2015. The analysis of the water balance components for the period 1981-2015 proved that due to the constant increases in the air temperature and evapotranspiration, there has been a decrease in runoff within Slovak river basins.

Drought indices are standardized statistical indicators derived from rainfall-deficit time series (Mishra and Singh, 2010). More than 100 drought indices have thus far been proposed, some of which are operationally used to characterize droughts using gridded maps on 
regional and national levels (Heim, 2002; Liu et al., 2018b; Vicente-Serrano et al., 2010; Vicente-Serrano et al., 2012). Popular and relatively frequently used drought indices derived from precipitation totals include the Standardized Precipitation Index (SPI), Percent of Normal Index (PNI), Deciles Index (DI), MCZI (modified CZI), and ZSI (Z-Score Index). A potentially important limitation of these indices is the omission of evapotranspiration, as the water available may be significantly reduced by evaporation in hot weather. This is addressed by several indices such as the Standardized Precipitation Evapotranspiration Index (SPEI), which extends the SPI method to include evapotranspiration, and the Potential Soil Moisture Deficit.

The aim of this work is: (i.) to quantify the deficit or surplus of the soil water supply through the daily values of the Effective Precipitation Index $\left(\mathrm{EP}_{365}\right)$ and MEP index at the research site in the selected years, and (ii.) to compare the development of the topsoil moisture regime through the use of the MEP index at the research site during dry and normal (slightly humid) periods.

\section{MATERIAL AND METHODS}

\subsection{Research site and database of precipitation totals}

The direct soil moisture measurements $(\theta)$ were carried out at the research site at the Slovak University of Agriculture (SUA), Dolná Malanta, Nitra $\left(48^{\circ} 19^{\prime} 00^{\prime \prime} \mathrm{N} ; 18^{\circ} 09^{\prime} 00^{\prime \prime} \mathrm{E}\right)$. The locality has a temperate climate, with a mean annual air temperature of $9.8^{\circ} \mathrm{C}$ and with mean maximum and minimum temperatures of $17^{\circ} \mathrm{C}$ (July) and $-3{ }^{\circ} \mathrm{C}$ (January). The mean annual precipitation at this site is 540 $\mathrm{mm}$ (150-200 mm between June and August). The neogene deposits consist of various clays, loams and sand gravels on which loess was deposited in the Pleistocene. The soil is classified as Haplic Luvisol according to the Soil Taxonomy (WRB, 2006) with $9.13 \mathrm{~g} \mathrm{~kg}^{-1}$ of organic carbon soil, $5.71 \mathrm{pH}$, and a silt loam texture (content of sand $15.2 \%$, silt $59.9 \%$, and clay $24.9 \%$ ).

The basic set of the input data were the daily precipitation totals $\left(H_{z}\right)$, which were measured at the meteorological station of the Department of Biometeorology and Hydrology of SUA in the period 2004-2018.

\subsection{Concept of Effective Precipitation}

Byun and Wilhite (1999) used the term "effective precipitation" to describe the summed value of daily precipitation with a timedependent reduction function, which represents the daily depletion of water resources. The choice of the best reduction function (equation) remains an unsolved problem because many parameters, such as the topography, soil characteristics, ability to keep water in reservoirs, air temperature, humidity, and wind speed, must be considered precisely together to represent the depletion of water resources in nature by runoff and evapotranspiration (Akhtari et al., 2009; Kalamaras et al., 2010; Kim and Byun, 2009; Kim et al., 2009; Morid et al., 2006; Roudier and Mahe, 2010).

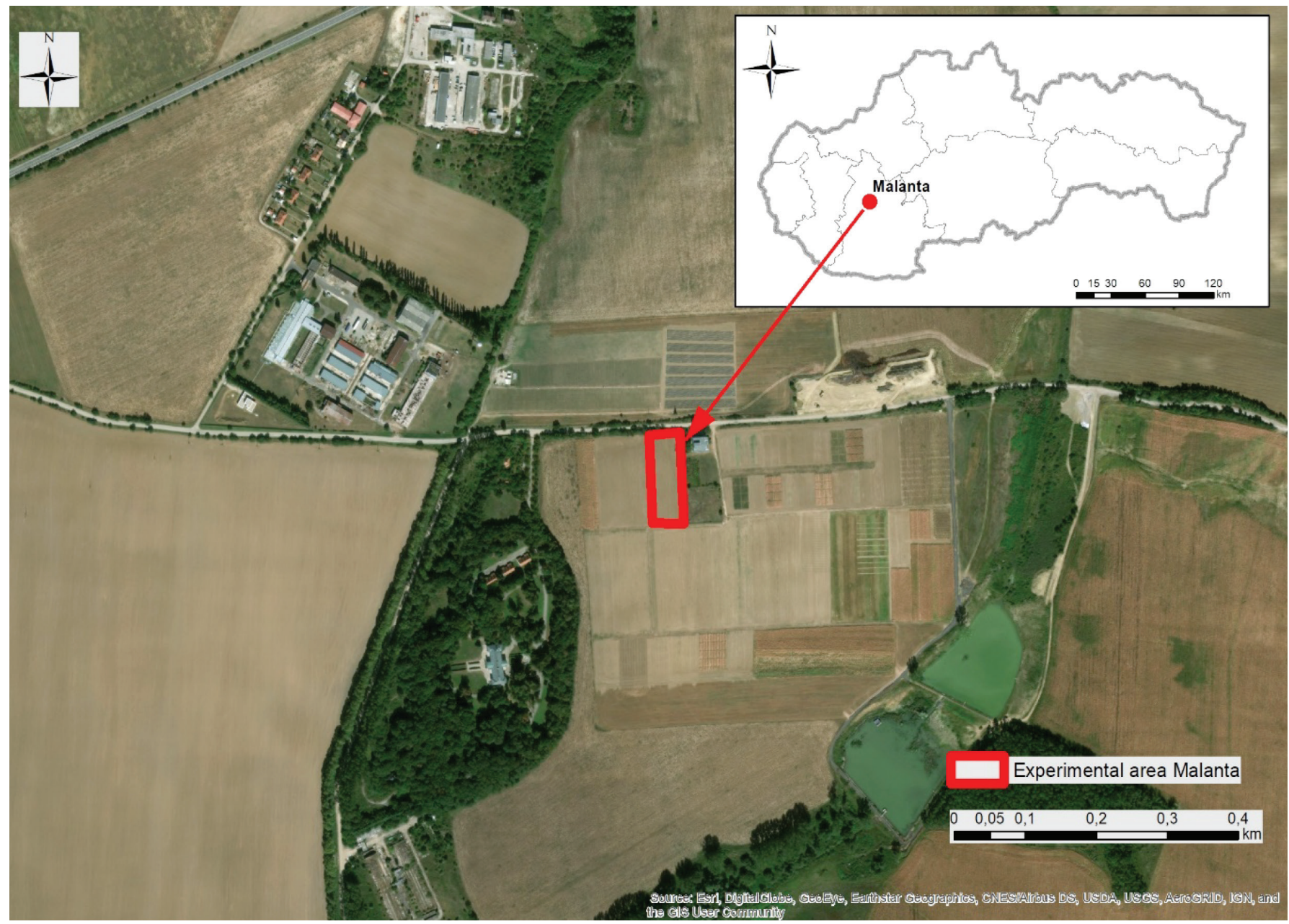

Fig. 1 The location of the Dolná Malanta experimental area 
The EPI is calculated in a daily time step to overcome the great limitation of other indices, i.e., a long-term unit of assessment (most current drought indexes use a monthly or longer time period as a unit).

The EP index is based on the calculation of the effective precipitation during the selected time period. For the purposes of this work, a 365-day effective precipitation $\left(\mathrm{EP}_{365}\right)$ and a linear reduction function were selected to represent a uniform loss of water resources throughout the year.

$$
\mathrm{EP}_{i}=\sum_{n=1}^{i}\left[\left(\sum_{m=1}^{n} H_{z m}\right) / n\right]
$$

where $i=$ number of days whose total precipitation is included in the EP calculation [-], $H_{z m}=$ total precipitation $m$-days before the first day included in the EP calculations ( $\mathrm{mm}$ ).

Precipitation totals from previous days of the assessment period are added to the total water supplies in the form of their average value. If $i=2$, then $m=[1,2]$, then

$$
\mathrm{EP}_{2}=\left[H_{z 1}+\left(H_{z 1}+H_{z 2}\right) / 2\right]
$$

In order to diagnose a complex drought, it is necessary to supplement the EP index with other derived values. The first is the value of the long-term EP average for each day of the calendar year (MEP). In this work, the average value of the effective precipitation was calculated from the 14-year series $\mathrm{EP}_{365}$ (period 2004-2018). The long-term EP $\left(\mathrm{MEP}_{\mathrm{n}}\right)$ for a normal (slightly humid) period in this work was computed for the years 2005-2012 and the long-term EP $\left(\mathrm{MEP}_{\mathrm{d}}\right)$ for a long-term dry period for the years 2012-2018. These time periods were selected according to the DEP index.
With respect to the long-term average, the surplus or scarcity of water resources (DEP) for each day of the period analyzed can be evaluated according to the equation:

$$
\mathrm{DEP}=\mathrm{EP}_{365}-\mathrm{MEP}
$$

\subsection{Statistical analysis}

The time series of the derived drought indices were compared with the measured values of the soil moisture using the Pearson correlation coefficient. The value range of the correlation coefficient is -1 to 1 . Values close to -1 indicate a strong negative relationship (high values of one variable generally indicate low values of the other). Values close to 1 indicate a strong positive relationship (high values of one variable generally indicate high values of the other). Values of the correlation coefficient close to 0 prove the non-existence of a linear relationship between these two variables.

\section{RESULTS AND DISCUSSION}

In the present study a 365-day effective precipitation $\left(\mathrm{EP}_{365}\right)$ was calculated. The course of the daily precipitation totals $\mathrm{Hz}$; the effective precipitation index $\mathrm{EP}_{365}$ and its long-term average value for a specific day (MEP) is graphically shown in Fig. 1.

A graphic presentation of the deficit or surplus of water resources (DEP) for each day of the period analyzed is shown in Fig. 2. Using this index, it is possible to identify dry periods in a daily step. Based on Fig. 2, it can be stated that dry periods prevailed during the years

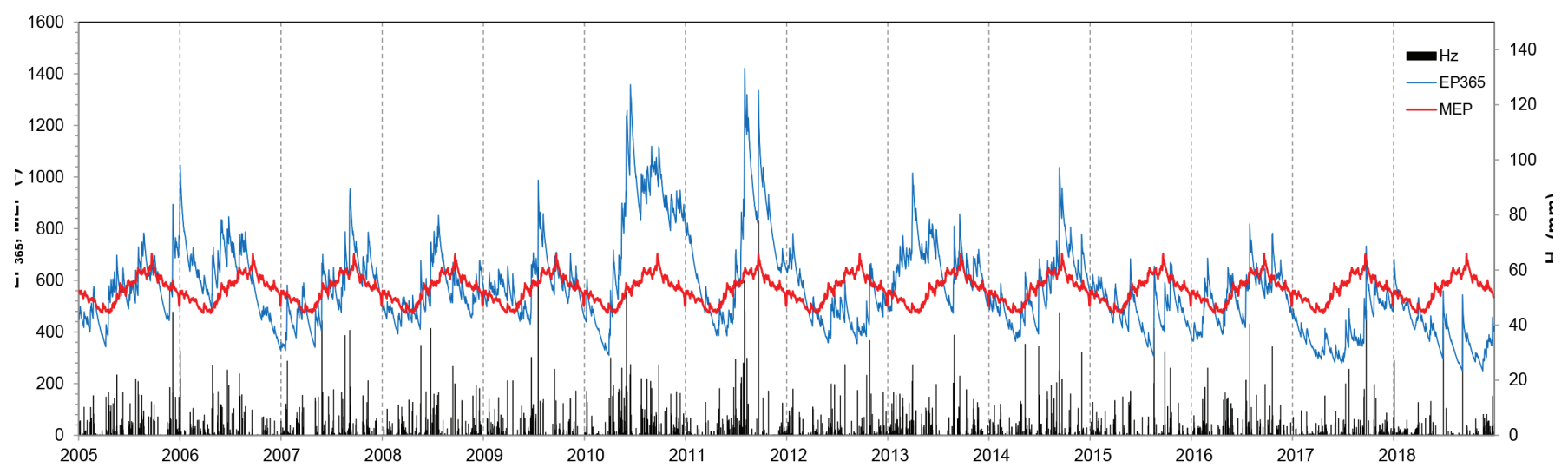

Fig. 2 Daily values of $\mathrm{Hz}, \mathrm{MEP}$ and $E P_{365}$ for the Nitra meteorological station for the period $2005-2018$

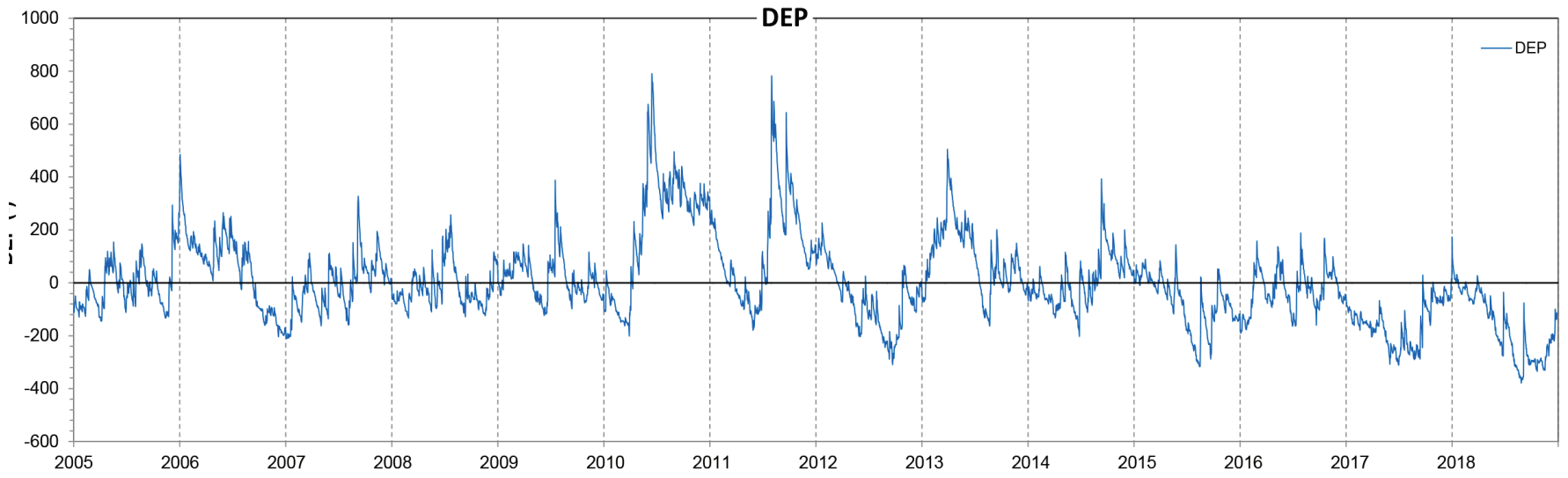

Fig. 3 Daily values of the DEP index for the Nitra meteorological station for the period 2005 - 2018 

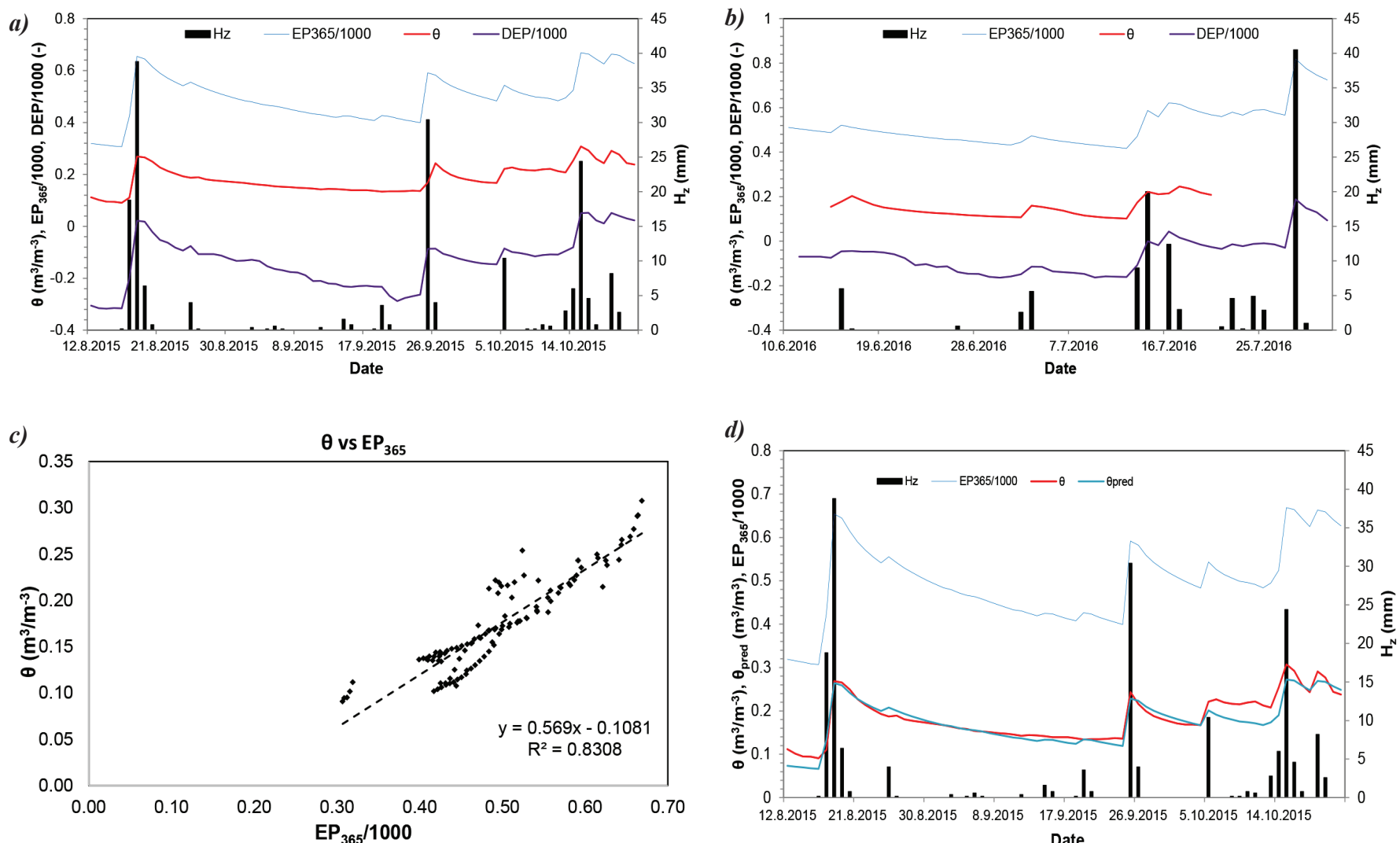

Fig. 4 a) Daily precipitation totals $(H z)$, measured soil moisture dynamics $(\theta)$ in the horizon $0-10 \mathrm{~cm}, D E P$ index and EP ${ }_{365}$ in the period 12.8. - 22.10.2015 b) in the period 14.6. - 20.7.2016; c) Correlation between the EP ${ }_{365}$ index and $\theta$ with the equation of the relationship and coefficient of determination; d) Daily precipitation totals (Hz), measured soil moisture dynamics $(\theta)$ in the horizon $0-10 \mathrm{~cm}, E P_{365}$ index and derived values of $\theta_{\text {pred }}$ in the period 12.8. -22.10.2015

2018, 2017 and 2015. The DEP index provides a more detailed view of the development of droughts than the monthly drought indices.

The correlation between the daily course of the $\mathrm{EP}_{365}$ index and the measured value of the soil moisture $(\boldsymbol{\theta})$ of the upper part $(10 \mathrm{~cm})$ of the soil profile of the research site was evaluated in the daily interval. The volumetric moisture content was measured in 5-minute intervals during two periods: 12.8 . -22.10 .2015 and 14.6. -20.7 .2016 .

Fig. 3a) shows the daily precipitation totals and soil moisture dynamics $(\boldsymbol{\theta})$ in the horizon $0-10 \mathrm{~cm}$ together with the values of the effective precipitation index $\mathrm{EP}_{365}$ for the first period, and Fig. 3b) shows them for the second period. The course of the $\mathrm{EP}_{365}$ index has

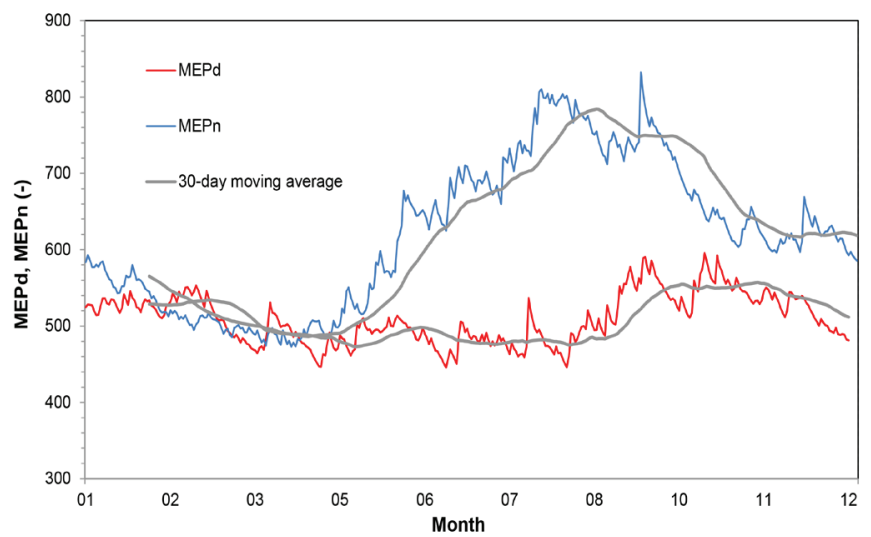

Fig. 5 The course of the MEPd and MEPn index (and its 30-day moving average) determined for a dry versus a normal year for the locality of Nitra a similar character as the measured values of the soil's volumetric moisture, while the $\mathrm{EP}_{365}$ index determined reacts more sensitively to the distribution of the precipitation totals than the measured values of the soil moisture. The correlation between the $\mathrm{EP}_{365}$ index and $\theta$ and the equation of the relationship is presented in Fig. 3c). The value of the coefficient of determination was 0.8308 , which represents a relatively strong correlation between the files evaluated. An estimated equation of the relationship between $\mathrm{EP}_{365}$ and $\boldsymbol{\theta}$ was used for determining the $\boldsymbol{\theta}_{\text {pred }}$ values, which are presented together with the original values of $\boldsymbol{\theta}$ at Fig. $3 \mathrm{~d}$ ). The values of $\boldsymbol{\theta}_{\text {pred }}$ derived from $\mathrm{EP}_{365}$ show a similar course as the measured values of $\boldsymbol{\theta}$, but only in the range of the measurements.

Based on the initial analysis, it can be said that both graphs capture the general trend of the moisture regime in the soil profile relatively well during the year for this geographical location.

Our next goal was to try to evaluate the long-term course of the moisture regime of the surface $(10 \mathrm{~cm})$ layer of the soil profile. According to the DEP index, we identified the normal (slightly humid) period of 2005-2011 (MEPn) and the dry period of 2012-2018 (MEPd). Fig. 4 is a graphic representation of the course of the moisture regime (represented by the MEP index) in both normal and dry years.

Fig. 4 shows a slight decrease in both MEPd and MEPn (representing water supplies) during the turn of the winter and spring, followed by a relatively sharp increase from the beginning of May in the normal year MEPn. This trend continues until August - mid-September, followed by a decline (in water supply) until the winter. In a dry year, the MEPd (water supply) increase does not occur till the autumn period, when after a small peak, the trend approximately begins to resemble the normal year mode of the moisture regime. 


\section{CONCLUSIONS}

Due to the lack of directly measured soil moisture $(\theta)$ values and the difficulty with their spatial extrapolation, alternative methods of soil drought characterization have been developed. The main cause of the drought is the lack of precipitation, relative to the climatic average of the area, therefore the most common approach uses drought indices derived from climatic characteristics. In our study, we used the daily values of Effective Precipitation Index (EP365) and the long-term EP average for each day of the calendar year (MEP) to quantify the deficit or surplus of the soil water supply at research locality Nitra. The deficit or surplus of water resources (DEP) for each day of the years 2005-2018 was determined, and the dry periods in a daily step were identified; droughts prevailed during the years 2018, 2017 and 2015. The DEP index provides a more detailed view of the development of drought than the monthly drought indices.

The second aim of our study was to compare the development of the topsoil moisture regime through the use of MEP index at research locality during the dry and normal (slightly humid) period. Relatively strong correlation between the $\mathrm{EP}_{365}$ index and measured $\theta$ in the upper $10 \mathrm{~cm}$ of the soil profile was found within the range of the actual soil moisture measurements.
We proposed a possible method for evaluating the long-term course of the moisture regime of the surface $(10 \mathrm{~cm})$ soil profile layer through the use of the MEP index. The MEP index captures the general trend of the moisture regime relatively well within the upper part of the soil profile during the year for this geographical location. The soil moisture regime in the dry and relatively normal year (expressed as the multiannual average of the MEP index values) showed significant differences in the course of the soil moisture curve. In a dry year, a relatively sharp increase in MEP (soil water supply) does not occur till the autumn period, when after small peak, the trend begins approximately resembling a normal year mode of moisture regime. However, further research with a longer time series is needed to verify the accuracy of the proposed method.

\section{Acknowledgements}

This work was supported by the Scientific Grant Agency No. VEGA 2/0053/18. 


\section{REFERENCES}

Akhtari, R. - Morid, S. - Mahdian, M.H. - Smakhtinm, V. (2009) Assessment of areal interpolation methods for spatial analysis of SPI and EDI drought indices. Int. J. Climatol. 29 (1), 135-145. https://doi.org/10.1002/joc.1691.

Brezianská, K. - Vitková, J. - Šurda, P. (2018) Analýza sucha a vplyv klimatických zmien na zásobu vody v pôde na Záhorskej nižine [Drought analysis and the impact of climate change on the water supply in the soils of Záhorská Lowlands]. In: Aktuálne problémy zóny aerácie pôdy v podmienkach prebiehajúcej klimatickej zmeny. - Bratislava : Veda, vydavatel'stvo Slovenskej akadémie vied, 2018, pp. 307-335.

Byun, H.R. - Wilhite, D.A. (1999) Objective quantification of drought severity and duration. Int. J. Climatol. 12 (9), 2747-2756.

Fendekova, M. - Gauster, T. - Labudova, L. - Vrablikova, D. Danacova, Z. - Fendek, M. - Pekarova, P. (2018) Analysing 21 st century meteorological and hydrological drought events in Slovakia. Journal of Hydrology and Hydromechanics, 66, 4, pp. 393-403.

Heim, R.R. (2002) A Review of Twentieth-Century Drought Indices Used in the United States. Bull. Amer. Meteor. Soc., 83, 11491166, https://doi.org/10.1175/1520-0477-83.8.1149.

Hlavčová, K. - Štefunková, Z. - Valent, P. - Kohnová, S. - Výleta, R. - Szolgay, J. (2016) Modelling the Climate Change Impact On Monthly Runoff in Central Slovakia. Procedia engineering, 161, 2127-2132.

Kalamaras, N. - Michalopoulou, H. - Byun, H.R. (2010) Detection of drought events in Greece using daily precipitation. Hydrol. Res. 41 (2), 126-133. https://doi.org/10.2166/nh.2010.001.

Kim, D.W. - Byun, H.R. (2009) Future pattern of Asian drought under global warming scenario. Theor. Appl. Climatol. 98 (1-2), 137-150. https://doi.org/10.1007/s00704-008-0100-y.

Kim, D.W. - Byun, H.R. - Choi, K.S. (2009) Evaluation, modification, and application of the Effective Drought Index to 200-Year drought climatology of Seoul Korea. J. Hydrol. 378 (1-2), 1-12. https://doi.org/10.1016/j.jhydrol.2009.08.021.

Liu, X. - Zhu, X. - Pan, Y. (2018) Performance of different drought indices for agriculture drought in the North China Plain. J. Arid Land 10, 507-516 https://doi.org/10.1007/s40333-018-0005-2.

Mishra, A.K. - Singh, V.P. (2010) A review of drought concepts. J. Hydrol. 391 (1-2), 202-216.

Morid, S. - Smakhtin, V. - Moghaddasi, M. (2006) Comparison of seven meteorological indices for drought monitoring in Iran. Int. J. Climatol. 26 (7), 971-985. https://doi.org/10.1002/joc.1264.
Nikolova, N. - Nejedlik., P. - Lapin, M. (2016) Temporal variability and spatial distribution of drought events in the lowlands of Slovakia. Geofizika, 33,2, pp. 119-135.

Roudier, P. - Mahe, G. (2010) Study of water stress and droughts with indicators using daily data on the Bani River (Niger basin, Mali). Int. J. Climatol. 30 (11), 1689-1705. https://doi. org/10.1002/joc.2013.

Šustek, Z. - Vido, J. - Škvareninová, J. - Škvarenina J. - Šurda, P. (2017) Drought impact on ground beetle assemblages (Coleoptera,Carabidae) in Norway spruce forests with different management after windstorm damage - a case study from Tatra Mts. (Slovakia). J. Hydrol. Hydromech., 65, 4, 333-342.

Vicente-Serrano, S.M. - Beguería, S. - López-Moreno, J.I. (2010) A Multiscalar Drought Index Sensitive to Global Warming: The Standardized Precipitation Evapotranspiration Index. J. Climate, 23, 1696-1718, https://doi.org/10.1175/2009JCLI2909.1.

Vicente-Serrano, S.M. - Beguería, S. - Camarero, J.J. - López-Moreno, J.I. - Azorin-Molina, C. - Revuelto, J. - Morán-Tejeda E. Sanchez-Lorenzo, A. (2012) Performance of Drought Indices for Ecological, Agricultural, and Hydrological Applications. Earth Interact., 16, 1-27, https://doi.org/10.1175/2012EI000434.1.

Vido, J. - Střelcová, K. - Nalevanková, P. - Leštianska, A. - Kandrík, R. - Pástorová, A. - Škvarenina, J. - Tadesse, T. (2016) Identifying the relationships of climate and physiological responses of a beech forest using the Standardised Precipitation Index: a case study for Slovakia. J. Hydrol. Hydromech., 64, 3, 246-251.

Vido, J. - Tadesse, T. - Sustek, Z. - Kandrik, R. - Hanzelova, M. Skvarenina, J. - Skvareninova, J. - Hayes, M. (2015) Drought Occurrence in Central European Mountainous Region (Tatra National Park, Slovakia) within the Period 1961-2010. Advances in Meteorology. Article Number: 248728.

WRB (2006) World Reference Base for Soil Resources 2006. 2nd edition. World Soil Resources Reports No. 103. FAO, Rome.

Zargar, A. - Sadiq, R. - Naser, B. - Khan, FI. (2011) A review of drought indices. Environmental Reviews 19: 333-349. https://doi. org/10.1139/a11-013.

Zuzulová, V. - Šiška, B. - Vavrovič, J. (2014) Evaluation of drought in Slovakia by the Palmer Drought Severity Index (PDSI) in the conditions of changing climate. In: Extrémy oběhu vody v krajině: Mikulov, 8-9 April 2014, edited by Rožnovský, J., Litschmann, T., Středa, T. and Stř̌edová, H. ČHMU, Prag, ISBN 978-80-87577-30-1. 